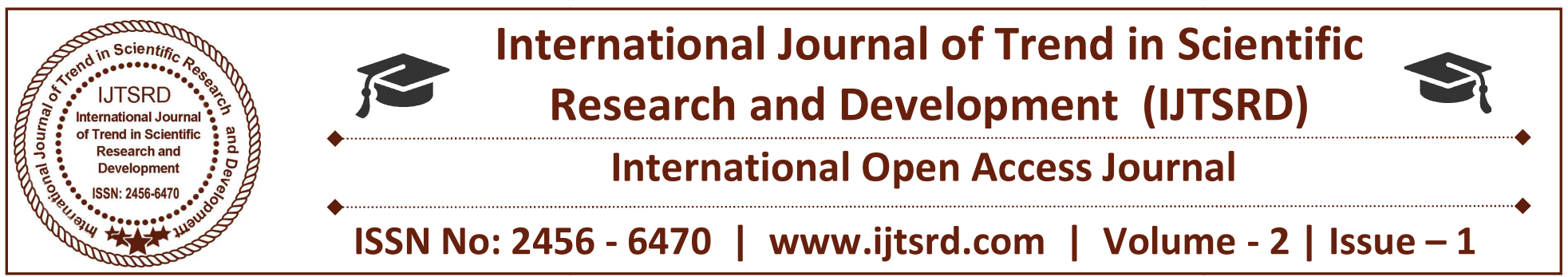

\title{
Impact of Motivational Factors of Public Sector Bank Employees - An Analysis
}

\author{
S. Nava Rethna Bala Kumari \\ Research Scholar, Research Centre in Commerce, \\ Women's Christian College, Nagercoil
}

\author{
Dr. R. Rathiha \\ Associate Professor of Commerce \\ Women's Christian College, Nagercoil
}

\begin{abstract}
An important role of management is to help make work more satisfying and rewarding for employees and to make employees' motivation consistent with organizational objectives. With the diversity of contemporary workplaces, this is a complex task. Many factors, including the influences of different cultures, affect what people value and what is rewarding to them. From a manager's perspective, this study tries to understand what prompts people, what influences them, and why they persist in particular actions. This study also intends to evaluate motivation of employees in the organization. A good motivational program procedure is essential to achieve goal of the organization. If efficient motivational programmers of employees are made not only in this particular organization but also in any other organization, the organizations can achieve the efficiency also to develop a good organizational culture and the attainment of organizational goals at large.
\end{abstract}

Keywords: Motivation, organizational behavior, performance, employee.

\section{Introduction:}

The concept motive is defined as a drive that leads to the motivation of employees in the workplace. Motivation is a key factor in social services and equally valuable to the social work manager. Motivation is to maintain and control the behavior of desirable actions as a stimulant. The importance of motivation reflect simple in theory, but it is difficult to measure experience. Payment is often enough to make the organization of employees, but not sufficient to achieve its potential. Motivated employees to maintain a high level of innovation, while producing higher quality work at a higher level of efficiency. It is empirically tested that the level of motivation is relatively low in public sector organizations as compare to private sector organizations in developing economies. There are very few public sector organizations that keep their employees motivated and earn higher returns whereas banks are highly known for heavy work load, long working hours and least motivated employees. The gap in literature was identified to examine the factors which are responsible for low level of motivation of employees and their demographic reflections of public sector organizations therefore this study will focus on the Banking Sector.

Since the beginning of time, leaders have risen to take charge of societies and make decisions. These decisions often meant the difference between having food and going hungry, having shelter or being homeless, and sometimes the difference between life and death. As society progressed, there have been great technological advances which have brought convenience to our lives. Despite having advancements, the basic needs for humans still remain the same. A question often asked by managers is, "How do we motivate our employees?" Effectively motivating employees to achieve a desired outcome is 
one of the most important functions of a manager. There is evidence to show organizations are facing challenges retaining employees due to limited opportunities for advancement and the current competitive labour market. It does not appear things will get any better in the future. The loss of employees represents a loss of skills, knowledge, and experiences and can create a significant economic impact and cost to corporations as well as impacting the needs of customers. Managers who can motivate employees assist the organization by improving employee retention and reinforcing positive behaviours and consequently, their enduring ability to motivate workers to achieve the highest result determines the success of a business. Motivation is the intention of achieving a goal, an ability to change behaviour, that inner directing drive, leading to goaldirected behaviour towards the attaining goal. Rewards can be either non-monetary or monetary. The following is the proposed model of impact of motivation on employees ${ }^{\text {ee }}$ performance. The proposed model would be tested with empirical analysis in order to identify the model fit.

Basic to any explanation of why people behave in a certain manner is a theory of motivation. As Jones (1959), cited in Lawler (1969), pointed out that motivation theory attempts to explain "how behavior gets started, is energized, is sustained, is directed, is stopped and what kind of subjective reaction is present in the organism. The theory of motivation that will be used to understand employees performance is "expectancy theory" (Vroom, 1964as described by Robbins (1998). The expectancy theory used is based upon Lawier and Porter (1967), Porter and Lawier (1968) as quoted by Robertand Hunt (1991). According to this theory, an employee's motivation to perform effectively is determined by two variables. The first of these is contained in the concept of an effort-reward probability. This is the individual's subjective probability that directing a given amount of effort toward performing effectively will result in his obtaining a given reward or positively valued outcome. Specifically relevant here is the list of needs suggested by Maslow that includes security needs, social needs, esteem needs, and self-actualization needs (Herzberg, 1987). The evidence indicates that, for a given reward, reward value and the effort-reward probability combine multiplicatively in order to determine an individual's motivation. This means that if either is low or not existing then no motivation will be present. According to Lawler (1969), they illustrate a case of a manager who very much value getting promoted but who sees no relationship between working hard and getting promoted. To him, promotion does not serve as a motivator, just as it is not for a manager who sees a close connection between being promoted and working hard but who does not want to be promoted. In order for motivation to be present, the manager must both value promotion and see the relationship between his efforts and promotion.

\section{REVIEW OF LITEATURE}

Berman, Bowman, West, \& Wart, (2010) in his study "Motivation: Possible, Probable or Impossible, Human Resource Management in Public Service: Paradoxes, Processes and Problems ", says that The concept of motivation is derived from a Latin word "movere" which means "to move". Motivation is what moves the employees from dullness to interest. It is just like the steering of the vehicles that directs and shapes employees' activities. Motivation has been defined as the "Drive or energy that compels people to act with energy and persistence towards some goal.

Rakesh K.Chopra (2006) in his book "Management of Human Resource-Text and Cases", explain that some job conditions dissatisfy employees when the conditions are absent, but their presences do not motivate employees in a strong way. Many of these factors are traditionally perceived by management as motivators, but these are really more potent as dissatisfies

\section{OBJECTIVES OF THE STUDY:}

To find out the motivational factors that affect the job satisfaction of bank employees.

$>$ To find out the relationship between gender and motivational factors of bank employees

\section{RESEARCH METHODOLOGY}

\section{Sampling Design}

The sample of 210 employees from banking sector has been taken for this study. The data have been collected by using convenience sampling technique from the employees of banking sector.

\section{Tool of data collection}

Percentage, factor analysis, t-test and are used in the study for analysis. 
DATA ANALYSIS

TABLE: 1

DEMOGRAPHIC PROFILE OF THE RESPONDENTS

\begin{tabular}{|c|c|c|c|}
\hline \multirow{2}{*}{ Age } & Nemographic & 88 & Percentage \\
\cline { 2 - 4 } & $21-30$ & 83 & 41.90 \\
\cline { 2 - 4 } & $31-40$ & 23 & 39.52 \\
\cline { 2 - 4 } & $41-50$ & 16 & 10.95 \\
\hline \multirow{4}{*}{ Total } & Above 50 & $\mathbf{2 1 0}$ & 7.63 \\
\hline \multirow{2}{*}{ Gender } & & 75 & $\mathbf{1 0 0}$ \\
\cline { 2 - 4 } & Male & 135 & 64.72 \\
\hline Total & Female & $\mathbf{2 1 0}$ & $\mathbf{1 0 0}$ \\
\hline \multirow{2}{*}{ Qualification } & Under Graduate & 38 & 18.10 \\
\cline { 2 - 4 } & Post Graduate & 72 & 34.28 \\
\cline { 2 - 4 } & Professional & 69 & 32.86 \\
\cline { 2 - 4 } & Others & 31 & 14.76 \\
\hline Total & & $\mathbf{2 1 0}$ & $\mathbf{1 0 0}$ \\
\hline
\end{tabular}

Source: Primary data

The above table exhibits that majority (41.9 percentage) of the respondents belong to the age group of 21-30. 64.28 percentages of the respondents were female and 34.28 percentage of the respondents have completed their post graduate level of education.

TABLE: 2

ROTATED COMPONENT MATRIX FOR MOTIVATIONAL FACTORS OF BANK EMPLOYEES

\begin{tabular}{|c|c|c|c|c|}
\hline Sl:NO & Motivational factors & $\begin{array}{c}\text { Work } \\
\text { Environment }\end{array}$ & Benefits & $\begin{array}{c}\text { Work } \\
\text { Enhancement }\end{array}$ \\
\hline 1 & Achievement & 0.666 & & \\
\hline 2 & Advancement & 0.650 & & \\
\hline 3 & Interpersonal Relations & 0.583 & & \\
\hline 4 & Working Conditions & 0.489 & & \\
\hline 5 & Salary & & 0.736 & \\
\hline 6 & Medical benefits & & 0.703 & \\
\hline 7 & After service benefits & & 0.665 & \\
\hline 8 & Status & & 0.653 & \\
\hline 9 & Responsibility & & & 0.821 \\
\hline 10 & Recognition & & & 0.817 \\
\hline 11 & Supervision & & & 0.608 \\
\hline 12 & Policy & & & 0.525 \\
\hline & Eigen value & 2.006 & 1.487 & 1.192 \\
\hline & Percentage of variation explained & 11.746 & 10.033 & 9.241 \\
\hline & $\begin{array}{c}\text { KMO measure of sampling } \\
\text { Adequacy:0.573 }\end{array}$ & \multicolumn{3}{|c|}{$\begin{array}{c}\text { Bartlett's test of sphericity: } \\
\text { Chi-square value:1290.464 } \\
\text { DF:28 } \\
\text { Significance value:.000 }\end{array}$} \\
\hline
\end{tabular}

Extraction method: Principal component analysis 


\section{Rotation method: Varimax with Kaiser Normalization}

The KMO value is very high (.573). Similarly, the Bartlett's test of sphericity has been conducted to test the validity of data, and the Chi-square value is 1290.464 at 28 degrees of freedom which is Significance value at five percent level. The above table indicates the rotated factor for the twelve variables. It is clear from the table that all the twelve variables have been extracted into three factors. The number of variables in each factor, Eigen value and the percent of variance explained by the factor are presented in the Table 3.

TABLE: 3

FACTOR LOADING FOR EMPLOYEES' MOTIVATION

\begin{tabular}{|c|c|c|c|c|c|}
\hline SI:NO & Factors & $\begin{array}{c}\text { Number of } \\
\text { variables }\end{array}$ & Eigen value & $\begin{array}{c}\text { Percentage } \\
\text { of variation } \\
\text { explained }\end{array}$ & $\begin{array}{c}\text { Cumulativepercentage } \\
\text { of variation explained }\end{array}$ \\
\hline $\mathbf{1}$ & Work Environment & 4 & 2.006 & 11.746 & 11.746 \\
\hline $\mathbf{2}$ & Benefits & 4 & 1.487 & 10.033 & 21.779 \\
\hline $\mathbf{3}$ & Work Enhancement & 4 & 1.192 & 9.241 & 31.020 \\
\hline
\end{tabular}

\section{Source: Computed data}

The most important motivation factor is 'Work Environment' since its Eigen value is 2.006. The 'Work Environment' has the percentage of variance of 11.746. In this factor the variables, 'Achievement' 'Advancement' 'Interpersonal Relations' 'Working Conditions' are included with high value of .666, .650, .583 and .489 respectively. The next factor is 'Benefits' which has the percentage of variance of 10.033 and its Eigen value is 1.487. 'Salary' 'Medical benefits' 'after service benefits' 'Status' since the value is .736, .703, .665 and .653 respectively. The last factor is 'Work Enhancement' since the Eigen value is 1.192 and has the percentage of variance of 9.241.These factor includes 'Responsibility', 'Recognition', 'Supervision' and 'Policy' since the value is $.821, .817, .608$ and .525 respectively.

\section{TABLE: 4}

IMPACT OF EMPLOYEE'S MOTIVATION

\begin{tabular}{|c|c|c|c|c|c|}
\hline \multirow{2}{*}{ SI:No } & \multicolumn{2}{|c|}{$\begin{array}{c}\text { Impact of employee's } \\
\text { motivation }\end{array}$} & \multicolumn{2}{|c|}{$\begin{array}{c}\text { Mean score } \\
\text { Statistics }\end{array}$} & $\begin{array}{c}\text { P- } \\
\text { Value }\end{array}$ \\
\cline { 3 - 5 } & Male & Female & & \\
\hline $\mathbf{1 .}$ & Achievement & 3.5556 & 3.2381 & $3.898^{*}$ & .000 \\
\hline $\mathbf{2 .}$ & Advancement & 3.9630 & 3.8095 & .652 & .408 \\
\hline $\mathbf{3 .}$ & Interpersonal Relations & 3.1481 & 3.2381 & -.378 & .308 \\
\hline $\mathbf{4 .}$ & Working Conditions & 2.9259 & 2.9259 & -.100 & .852 \\
\hline $\mathbf{5 .}$ & Salary & 2.9074 & 2.8095 & $4.507^{*}$ & .000 \\
\hline $\mathbf{6 .}$ & Medical benefits & 3.4074 & 3.0476 & 1.645 & .101 \\
\hline $\mathbf{7 .}$ & After service benefits & 3.4259 & 3.5714 & -.576 & .198 \\
\hline $\mathbf{8 .}$ & Status & 2.9630 & 2.7619 & $2.188^{*}$ & .029 \\
\hline $\mathbf{9 .}$ & Responsibility & 2.7778 & 2.7143 & $2.188^{*}$ & .029 \\
\hline $\mathbf{1 0 .}$ & Recognition & 2.6564 & 2.7765 & .345 & .730 \\
\hline $\mathbf{1 1 .}$ & Supervision & 3.6667 & 3.2436 & $2.558^{*}$ & .011 \\
\hline $\mathbf{1 2 .}$ & Policy & 2.3534 & 2.9897 & $2.174^{*}$ & .030 \\
\hline & Overall motivation & 2.8518 & 3.1240 & & \\
\hline
\end{tabular}

Source: Primary data

*Significant at 5\% level 
Table 4 reveals that Male employees' have the highest motivation factor for the variables 'Advancement' and 'Achievement' since they have the highest mean scores of 3.9630 and 3.5556 respectively. They have the lowest motivation factor for the variables 'Responsibility' and 'Policy', since they have the lowest mean scores of 2.7778 and 2.3534 respectively. Female employees' have the highest motivation factor for the variables 'Advancement' and 'after service benefits' since they have the highest mean score of 3.8095 and 3.5714 respectively. They have the lowest motivation factor for the variables 'Responsibility' and 'Status' since they have the lowest mean score of 2.7143 and 2.7619 respectively.

Regarding the impact of employees motivation factor in male and female, significant difference have been identified in the case of six variables, 'Achievement', 'Salary', 'Status', 'Responsibility', 'Supervision' and 'Policy' since their respective ' $t$ ' statistic are significant at five percent level.

\section{SUGGESTIONS}

Money alone is not enough to motivate employees in today's workforce. Besides financial motivations, other ways are to be adopted to motivate employees such as involving them in decision making - process, autonomy in work which ensures a healthy environment.

* Employees should be encouraged to commit themselves to create a dedicated workforce for banking institution.

* Banks should take measures to change the attitude of the employees towards work and also to increase the level of interest towards their work.

\section{CONCLUSION}

This empirical study was carried out to identify the impact of motivation factor of bank employee. If managers wish to be effective, they need to have at least a basic understanding of motivation and the different motivational theories that try to explain the concept of motivation. Managers need to provide growth opportunity and challenging jobs in order to better motivate today's workers. Without these challenges and opportunities for growth, employees may not see a need to perform highly at work. We have seen that recognition plays a major role in employees' motivation and that it is a very effective motivator. Employees want and need to feel that their contributions make a difference and recognition is one way to satisfy those wants or needs.

\section{REFERENCES}

1) Bateman TS, Snell SA (2004). "Management: The new competitive landscape", Mc Graw Hill, New York 6th Ed., pp.407-418.

2) Child J (1984). "Organisation: A guide to Problems and Practice”, PCP Publishing, 2nd Ed. pp.172-180.

3) Daniel KJ (2001). "The effects of employee satisfaction, organisational citizenship behaviour and turnover on organisational effectiveness", $\boldsymbol{A}$ unit level, longitudinal study. Pers. Psychol. 54(1):101-114.

4) Edwin A (1993). "Comparism and Motivation: maximising employee performance with behaviour-based incentive plans", Pers. Psychol. 46:407-411.

5) Bolman, L.G. \& Deal, T.E., (2008). "Reframing Organizations ", London: John Wiley \& Sons.

6) Baeten, G., (2000). "The tragedy of the highway: Empowerment, disempowerment and thepolitics of sustainability discourses and practices", European Planning Studies, 8(1), 69-86.

7) Daft, R.L. \& Marcic, D., (2011), “Understanding Management", New York: Cengage

8) Learning.Grönroos, C., (2001), “Service reflections: Service marketing comes of age",Thousand Oaks, CA: Sage.

9) Harter, J.K., Schmidt, F.L. \& Hayes, T.L., (2003), "Business-unit level relationship betweenemployee satisfaction, employee engagement, and business outcomes: a metaanalysis", Journal of Applied Psychology, pp.269-78.

10) Berman, E. M., Bowman, J. S., West, J. P., \& Wart, M. R. V. (2010). "Motivation: Possible, Probable or Impossible, Human Resource Management in Public Service: Paradoxes, Processes and Problems", (pp. 180). California: SAGE Publications,

11) Rakesh K.Chopra (2006) in his book "Management of Human Resource-Text and Cases", Kithab Mahal, Allahabad, Pp.458-460 